\title{
Leadership Style of Religious School Headmasters and Its Relationship to Academic Achievement in Brunei Darussalam
}

\author{
Gamal Abdul Nasir Zakaria ${ }^{1}$, Halimah Kamis ${ }^{2}$, Salwa Mahalle ${ }^{3}$ \& Aliff Nawi ${ }^{1}$ \\ ${ }^{1}$ Language and Literacy Education Academic Group, Sultan Hassanal Bolkiah Institute of Education, Universiti \\ Brunei Darussalam, Brunei \\ ${ }^{2}$ Tutong Religious School, Brunei \\ ${ }^{3}$ Psychological Studies and Human Development Academic Group Sultan Hassanal Bolkiah Institute of \\ Education, Universiti Brunei Darussalam, Brunei \\ Correspondence: Gamal Abdul Nasir Zakaria, Language and Literacy Education Academic Group, Sultan \\ Hassanal Bolkiah Institute of Education, Universiti Brunei Darussalam, Brunei. E-mail: \\ gamal.zakaria@ubd.edu.bn
}

Received: December 2, 2013 Accepted: December 31, 2013 Online Published: January 27, 2014

doi:10.5539/ass.v10n3p112 URL: http://dx.doi.org/10.5539/ass.v10n3p112

\begin{abstract}
This research was conducted at 15 religious schools in Tutong District. The objectives of this research are to identify leadearship style and its relationship to academic achievement. The "Leader Behaviour Description Questionnaire" (LBDQ) formed by Halpin (1966) was used. Meanwhile Academic achievement was measured using the "School Certificate Examination Results, Religious Primary School (SSSRU) from 2008-2011. A total of 191 teachers and 15 headmasters from religious school in Tutong District were randomly chosen. Pearson correlation was used to analyse the data. To support data obtained from questionnaire given 10 teachers were interviewed. The results showed that most of the school leaders adopt a democratic style of leadership. There was a significant correlation between the structure of task-oriented leadership style and students' performance in the examinations. Correlation analysis also showed that headmasters practice task- oriented structure and consideration-oriented structure in relation to their work responsiblities. Furthermore, findings also showed that majority of the headmasters are more likely to practice consideration-oriented leadership style compared to structure-oriented leadership style.
\end{abstract}

Keywords: leadership style, religious school, headmasters, academic achievement

\section{Introduction}

Head masters or principals often play the role of both leader and manager. According to Abdul Aziz (2000), they are professional leaders who assume two roles that complement each other, namely leadership and management. The principal is the fundamental leader in a school and on whose shoulders lie the hopes of parents, students, teachers, the community and the governement. Mulyasa (2009) believes that principals are the key element in raising the quality of education in a school hence making them the most important individual in a school organisation. The concomitant heavy workloads are thus inevitable and consequently such circumstances can cause many principals to fail to manage and run a school effectively.

As the main backbone of their school, the principals' leadership style can help create a pleasant working environment and encourage the enhancement of performance among teachers and other members of the school staff. Principals have the responsibility and authority to develop school plans to improve their schools. This authority enables principals to either promote schools that strive to achieve both academic and co-curricular excellence, or create ones that are unsuccessful and ineffective (Yahya, 2005).

Principals must develop strategies that can improve the professionalism of the teaching staff in their schools. This includes creating a school environment that is conducive to learning and providing counsel, especially for teachers, in implementing attractive teaching models such as team teaching and the moving class system (Mulyasa, 2009). Mulyasa further asserts that principals and educators should become a learning person who would continuously strive to upgrade their knowledge and skills. Principals should thus be equipped with skills qualities including leadership skills, technical skills, humanitarian skills, educational skills, cultural skills, 
communication skills, motivational skills as well as decision-making and problem solving skills. Apart from that, they should also be physically, emotionally and spriritually stable, and highly ethical.

\section{Background of the Study}

A leader is an individual in a particular group or organisation that has been given the responsibility to direct and coordinate activities that seek to achieve the objectives of the group or organisation. This means that leadership is a process that influences group activities and drives them towards the accomplishment of a particular planned outcome (Ibrahim, 1993).

In the school context, it is essential that schools are led by competent leaders whose influence is crucial for the accomplishment of the educational institution. The success of a school is dependent on a lot of factors, which among other things include teachers, students, facilities and the learning environment. Bright students, for instance, undoubtedly contribute to the performance of a school, and so do dedicated teachers and adequate school facilities. However, studies indicate that the leadership qualities of the principal can exert an enormous influence on the quality and success of a school, the students' performance as well as the teachers' capabilities.

On the basis of a study on effective schools, Hussein (1993) states that the role of the principal is often alluded to as a contributing factor towards the success of a school. Consequently, principals must play their pivotal role effectively so that the school can continuously strive for excellence. Competent principals can direct and monitor the development of the school because they are the leaders with the power and authority to lead the school. They are also individuals who are always expected to be in the forefront particularly when facing any critical situations that concern the school (Yahya, 2005).

In the education system of a particular country, principals or headmasters are given the responsibilities to manage the direction of the school in order to achieve the vision and mission that have been developed. Specifically, the principal is the manager and administrator of the school assets; the human element (teachers, students and other employees) and the non-human element (premises, buildings, teaching aids) (Ibrahim, 2001). In managing a school, the principal must implement activities that exhibit planning, leadership and efforts that can detect and resolve problems encountered by the school (Omardin, 1999). In a nutshell, there is evidence to suggest that a dynamic principal can lead to immense success of a school (Ibrahim, 1993). As a school leader, the principal can result in the change that is highly desired by the school by generating collaborative team work with teachers, other members of the school staff and the surrounding community.

\section{Theoretical Background}

This research is based on the theoretical framework introduced by Likert (1969) whereby Likert had identified that there are two different styles of leadership namely leadership which is oriented towards tasks and leadership which is oriented towards the relationship with employees. Leaders who practised the taskes oriented leadership style are those who are being autocratic and depends on their power and position to influence their sub-ordinates.This type of leaders are usually very strict and always make sure that the employees follow the rules and regulations set in order to perform well in their tasks. Fleishman (1973) believed that the Tasks-oriented leadership style can determine clearly of the tasks one has to handle. This was further emphasised by Jami Salih (2003) where a leader of this type works best based on giving his sub-ordinates the schedule for tasks and trying out new ideas.

Meanwhile, leaders who are employee oriented would be regarded as leaders who are democratic who always give space and chance for his employees to be involved in any process of decision-making. According to Hersey and Blanchard (1982), leadership style of a leader can indirectly influence the behaviours of others. Hence, a leader should be aware of the leadership style he is implementing because he will always be observed by his sub-ordinates.

\section{Statement of the Problem}

Results of the Religious Primary School Examination from 2008-11 have shown that the passing percentages for Religious School in Tutong district were at their highest level (Reports from the Examination Unit, Department of Islamic Studies, Ministry of Religious Affairs, 2012). Place Based on the examination results according to districts and zones, Tutong District was still at the top level (see Table 1). 
Table 1. Percentages of passes: District wise (2008-2011)

\begin{tabular}{ccccc}
\hline & \multicolumn{3}{c}{ Percentages of Passes } \\
District & 2008 & 2009 & 2010 & 2011 \\
\hline Brunei/Muara & 81.12 & 91.31 & 89.24 & 90.78 \\
Tutong * & 97.49 & 95.26 & 97.62 & 96.88 \\
Belait & 94.29 & 89.47 & 95.22 & 91.49 \\
Temburong & 82.88 & 84.35 & 86.96 & 95.28 \\
\hline
\end{tabular}

The above table (Table 1) shows that the percentages of student passers in the Tutong District outstand the other districts. Although there was a decrease of 1\% from the year 2010 to 2011, nevertheless the percentages of student passers were still dominant in the Tutong District. Hence, it is distinctively shown from the table that since 2008-2011, the said district acquired the highest percentages of student passers. In addition, it can be seen that in 2008, there were $97.49 \%$ of passers, in 2009 it was $95.26 \%$, slight increase in 2010 (97.62\%) and in 2011, the percentage was $96.88 \%$. (see Table 2 ).

Table 2. Percentages of passes in the religious primary school examination (2008-2011): Tutong district

\begin{tabular}{llcc}
\hline \multicolumn{4}{c}{ Percentages of Passes } \\
\hline 2008 & 2009 & 2010 & 2011 \\
97.49 & 95.26 & 97.62 & 96.88 \\
\hline
\end{tabular}

Looking at the good achievement obtained by the religious schools in Tutong District, therefore this study intends to see if the leadership styles practiced by the headmasters in the respective schools have any correlation with the students' achievement.

\section{Research Objective}

From the statement of problem, the objectives of this research are; 1) To examine the leadership style of the headmasters in the religious schools in the Tutong District; 2) To identify the correlation between the task-oriented leadership style and the students' achievement in the Religious Primary School Examination.

\section{Method}

The research design for this study was in the form of survey. According to Kerlinger (1986), constructing the research design isa very important process in order for the researcher to be able to answer the research question posed and the objectives outlined. As stated previously, one of the main objectives of this research was to investigate the leadership style practised by the religious teachers in the religious school in one of the districts in Brunei Darussalam. This research used quantitative approach where a total of 191 religious teachers from 15 religious schools out of 22 schools were involved.

The Leader Behaviour Description Questionnaire developed by Halpin was used in this research. The result of pilot study showed that the cronbach alpha is 0.922 , it means the level of realibility of this instrument is significant. Data from the questionnaire was analysed descriptively by using SPSS and Pearson correlation was used to see the relationship between the task-oriented and consideration-oriented leadership style and the students' achievement with correlation value r, ranging between 0 and $1(0<\mathrm{r}<1)$ whereby 0 denotes a very low correlation and 1 denotes the highest correlation value (Mohd Najib, 2003).

0.00-0.20: Very weak, very low correlation

0.21-0.40: Weak correlation

0.41-0.70: Average correlation

0.71-0.90: High correlation

0.91-1.0: Very high, very strong correlation

From the questionnaire given, there are 15 items which described characteristics of a leader. Likert scale was used ranging from 1 (Strongly Disagree) to 5 (Strongly Agree). The percentages for 'strongly disagree' and 'agree' were collapsed and the same thing goes to 'strongly agree' and 'agree' scale. This was done because 
researcher would only want to see the percentage differences for agree and disagree continua.

Researcher had randomised the schools to be selected. Out of the 22 religious schools, 15 schools were selected which comprised of more than a third of the total population of religious schools in that district. Further, all the students in Year 6 from 15 religious schools were chosen which totalled up to 191 students. Leader Behaviour Description Questionnaire (LBDQ) was used as the research instrument. This instrument was developed by Halpin (1966) which had been translated to Malay Language by Rahimah Ahmad (1981). LBDQ consists of 15 items which are all in the form of close-ended questions. Eventhough the items had been translated to Malay Language but for this research, the researcher had given to three experts in the area of leadership to validate these items.

Cronbach Alpha was used to test the reliability of the items and value obtained was 0.922 . This means that the items in LBDQ do measure the leadership style of religious teachers in one of the districts in Brunei Darussalam. In LBDQ, Halpin had outlined the the importance of the relationship between the leaders with their sub-ordinates and at the same time emphasising on the importance of the organisational structure, clear communication paths and regulations.

\section{Findings}

\subsection{Leaderships' Characteristics of the Headmasters: Frequencies and Percentages}

Table 3 shows a leaderships' characteristic of the Headmasters. From the results obtained, it can be seen that majority of the headmasters of the religious schools in the Tutong District have the characteristics of being effective and charismatic. Generally, all the item were very high level. The findings indicate that the leaderships' characteristic are at a satisfactory level based on the item scores at $77 \%$ and above.

Table 3. Leaderships' characteristics of the headmasters: Frequencies and percentages

\begin{tabular}{lrrrrrc}
\hline & \multicolumn{2}{c}{ Disagree } & \multicolumn{2}{c}{ Not Sure } & \multicolumn{2}{c}{ Agree } \\
& $\mathrm{N}$ & $\%$ & $\mathrm{~N}$ & $\%$ & $\mathrm{~N}$ & $\%$ \\
\hline Appreciate others & 1 & 0.5 & 43 & 22.5 & 147 & 77.0 \\
Able to communicate well & 2 & 1.0 & 22 & 11.5 & 167 & 87.4 \\
Able to plan well & 2 & 1.0 & 22 & 11.5 & 167 & 87.4 \\
Positive attitude \& open minded towards teachers & 3 & 1.5 & 23 & 12.0 & 165 & 86.4 \\
Well disciplined & 2 & 1.0 & 16 & 8.4 & 173 & 90.6 \\
Able to solve problems & 1 & 0.5 & 20 & 10.5 & 170 & 89.0 \\
Encourage participation from teachers & 3 & 1.6 & 32 & 16.8 & 165 & 81.7 \\
Has self respect towards others & 3 & 1.6 & 25 & 13.1 & 163 & 85.3 \\
Qualified,creative, knowledgable on the needs being a leader & 3 & 1.6 & 19 & 9.9 & 169 & 88.5 \\
Spiritual & 3 & 1.6 & 24 & 12.6 & 164 & 85.8 \\
Able to give new ideas with regard to teaching techniques & 1 & 0.5 & 39 & 20.4 & 151 & 79.1 \\
Ensuring the avalability of facilities in the teaching-learning & 2 & 1.0 & 26 & 13.6 & 163 & 85.4 \\
process & & & & & & \\
Ensuring the teachers are practising the philosophy of 'students & 1 & 0.5 & 15 & 7.9 & 174 & 91.1 \\
are able to improve their performance' & & & & & & \\
Helping teachers to improve their performance regarding & 5 & 2.6 & 14 & 7.3 & 172 & 90.0 \\
teaching-learning,to know the characteristics of an effective school & & & & & & \\
\hline N=No.of teachers responded & & & & &
\end{tabular}

According to the teachers, the top five leaderships' characteristics possessed by their headmasters were: having a strong belief and convince that students can improve (91.1\%), well-disciplined leader (90.6\%), like to help teachers in improving their performance especially with regard to teaching-learning $(90 \%)$, able to solve problems $(89 \%)$ and being a creative and knowledgable leader $(88.5 \%)$. 
While other item such as able to plan and communicate well obtain score $87.4 \%$ and being positive attitude and open minded towards teachers score $86.4 \%$. Similarly, the item which have a spiritual, ensuring the avalability of facilities in the teaching-learning process and self respect towards others got the same score which is $85 \%$. Also, the item 'encourage participation from teachers' score $81.7 \%$, 'able to give new ideas with regard to teaching techniques score $79.1 \%$ and 'appreciate others score $77 \%$.

\subsection{The Correlation between Task-Oriented Leadership Style and Students'Achievement}

In this section, there are 15 items which described the consideration aspect in a leadership style. Pearson correlation was used to see the relationship between the leadership style and the students' achievement in their Religious Primary School Examination from 2008-2011 with the significant level p=0.01.

Table 4. The correlation between task-oriented leadership style and students' achievement

\begin{tabular}{|c|c|c|c|c|}
\hline \multirow[t]{2}{*}{ Task-Oriented Leadership Style } & \multicolumn{4}{|c|}{ Students' achievement (Religious Primary School Exam) } \\
\hline & 2008 & 2009 & 2010 & 2011 \\
\hline To show firm stand in all matters & $\mathrm{r}=-0.397 * *$ & $\mathrm{r}=-0.306^{* *}$ & $\mathrm{r}=-0.215^{* *}$ & $r=-0.084$ \\
\hline Give personal help to teachers \& staff & $\mathrm{r}=-0.297 * *$ & $\mathrm{r}=-0.235^{*} *$ & $\mathrm{r}=-0.176$ & $\mathrm{r}=-0.023$ \\
\hline $\begin{array}{l}\text { Be attentive to small matters in order to help } \\
\text { teachers }\end{array}$ & $\mathrm{r}=-0.169$ & $\mathrm{r}=-0.244^{* *}$ & $\mathrm{r}=-0.176$ & $\mathrm{r}=-0.121$ \\
\hline Easily understood by all staffs & $\mathrm{r}=-0.333 * *$ & $\mathrm{r}=-0.249 * *$ & $\mathrm{r}=-0.318^{* *}$ & $\mathrm{r}=-0.217^{* *}$ \\
\hline Willing to listen to teachers' problems & $\mathrm{r}=-0.348^{* *}$ & $\mathrm{r}=-0.209 * *$ & $\mathrm{r}=-0.285^{* *}$ & $\mathrm{r}=-0.118$ \\
\hline Not being transparent on certain matters & $\mathrm{r}=-0.062$ & $\mathrm{r}=0.142$ & $\mathrm{r}=0.157$ & $\mathrm{r}=-0.047$ \\
\hline Care for teachers' and staffs' welfare & $\mathrm{r}=-0.324 * *$ & $\mathrm{r}=-0.239 * *$ & $\mathrm{r}=-0.222 * *$ & $\mathrm{r}=-0.096$ \\
\hline Don't explain clearly on the action taken & $\mathrm{r}=0.106$ & $\mathrm{r}=0.246^{* *}$ & $\mathrm{r}=0.159$ & $\mathrm{r}=-0.012$ \\
\hline Inform honestly on the teachers' performance & $\mathrm{r}=-0.111$ & $\mathrm{r}=-0.294 * *$ & $\mathrm{r}=0.037$ & $\mathrm{r}=0.074$ \\
\hline Treat every teachers equally & $\mathrm{r}=-0.369^{* *}$ & $\mathrm{r}=-0.263 * *$ & $\mathrm{r}=-0.294 * *$ & $\mathrm{r}=-0.193 * *$ \\
\hline Willing to accept changes & $\mathrm{r}=-0.394^{* *}$ & $\mathrm{r}=-0.201 * *$ & $\mathrm{r}=-0.343 * *$ & $\mathrm{r}=-0.190^{* *}$ \\
\hline Friendly and approachable & $\mathrm{r}=-0.311^{* *}$ & $\mathrm{r}=-0.118$ & $\mathrm{r}=-0.319 * *$ & $\mathrm{r}=-0.166$ \\
\hline Comfortable to talk with & $\mathrm{r}=-0.368^{* *}$ & $\mathrm{r}=-0.119$ & $\mathrm{r}=-0.386^{* *}$ & $\mathrm{r}=-0.248^{* *}$ \\
\hline Accept opinion/ideas from others & $\mathrm{r}=-0.295^{* *}$ & $\mathrm{r}=-0.151$ & $\mathrm{r}=-0.289 * *$ & $\mathrm{r}=-0.069$ \\
\hline $\begin{array}{l}\text { Ask for teachers' agreement before doing } \\
\text { anything }\end{array}$ & $\mathrm{r}=-0.201 * *$ & $\mathrm{r}=-0.163$ & $\mathrm{r}=0.289^{* *}$ & $\mathrm{r}=-0.156$ \\
\hline
\end{tabular}

Significant level $\mathrm{p}=0.01(\mathrm{p}>0.01)^{* *} \mathrm{r}=$ pearson's correlation value

From Table 4, it can be seen that there are quite a number of leadership styles which are correlated to the students' achievement (Religious Primary School Exam) although the correlation values $r$ are not strong. Some of the styles which are correlated with the students' achievement for 4 consecutive years (2008-2011) are like having a firm stand in all matters, easily understood by all staffs, treat everybody in the school equally and willing to accept changes. The significant level is at $\mathrm{p}=0.01$.

Furthermore, correlation is seen between the 'consideration-oriented' leadership style and the students' achievement for 3 consecutive years (2008-2011) although the correlation values are not strong, namely being firm, willing to listen to teachers' problems and feeling of care towards the teachers' welfare.

In 2008, there are 11 items on 'consideration-oriented' leadership styles which are weakly correlated to the students' achievement such as being firm in all tasks given, like to help teachers, easily understood and communicate well with teachers, being a good listener to the teachers' problems, practice no favouritism, open minded and willing to accept changes. On the other hand, in 2011, there are fewer 'consideration-oriented' leadership styles which correlate with the students' acievement, namely, being able to communicate and understand teachers' needs, no favouritism and able to adapt with new changes.

From the Table 4, it can be concluded that the headmasters in the religious schools in the Tutong District do 
practice being a considerate leader. The correlation between these practices and the students' achievement are not strong, hence showing that there may be other aspects that could contribute to the good results that the students have achieved such as teachers' motivation and teachers' commitment.

Having in mind that all of the headmasters have experience of less than 5 years being appointed as headmasters, it can be concluded that the type of leadership styles they used do not have strong correlation with the students' achievement. There could be other factors that may contribute to the students' excellent performance in their Religious Primary School Examination such as through the extra classes given during school holidays, remedial classes for the weaker students, teaching approaches used by teachers and so forth.

To conclude, the findings for this research clearly showed that leadership styles do affect the students' achievement. The findings too supported the research by Keith and Girling (1991) in 16 secondary schools in California whereby schools with considerate leaders and had good relationship with the students ultimately producing students who performed very well.

Studies done in Brunei such as by Miramit (2002), Maladiah (2008) and Rusli (2009) had proved that leadership style do have high impact towards the students' achievement and the teaching-learning process of the students which ultimately contribute to the excellent performance of the schools. In addition, research done in Malaysia also showed the same pattern such as studies by Jaafar (2002), Md Kher (2003), Jamil Salih (2003) and Md Yazid (2000).

\section{Discussions and Conclusions}

Based on the results that have been discussed, the study has found that the headmasters in the religious schools in the Tutong District practiced democratic leadership style. Also, this study found that there is a positive correlation between democratic leadership styles and positive outcomes rather than the causation of these variables being demonstrated. Numerous past researches too had proven that school leaders who practiced democratic leadership style can give positive impacts towards the excellence of the school teachers. For instance, Block (1993) supported that democratic leadership style can encourage effective surveillance and can get good committment from all members in the organisation. This is supported in a research done by Kouzes and Posner (1995) who had significantly identified that good communication skills too may act as the catalyst towards the success of an organisation.

In addition, data analysis also shows that the characteristics of the school leader is one of the key factors which contribute to the success of his or her sub-ordinates. This can be seen from the good rapport built between the school leaders and the teachers which ultimately can contribute to the good level of performance of the school. As supported by a research done by Persico (2001, in Syariffah, 2010), management and leadership style of the school leaders do affect the professional development of the teachers.

Research done by Antonio (2008) significantly found that a group which practices the democratic leadership style will have a higher level of committment and can be more trusted compared to a control group which practises democratic leadership style a year after. Hence, the factors which contribute to teachers', staffs' and employees' excellence in an organisation do have a strong and significant correlation with the practices of their leaders.

Leading a school can be a very challenging job. Thus, a leader must be creative, knowledgeable and willing to implement and accept changes especially for the betterment of the students' performance. As portray in the results, most of the headmasters were concern on their students' performance and achievement, emphasised on the importance of discipline in their schools, willing to help teachers to be more effective especially in their teaching-learning process. These can be seen from the data analysis which showed that most of the headmasters were qualified, open-minded, knowledgeable and able to make decisions. A research by Moller et al. (2007) also showed that values such as giving encouragement, fairness in school or in a community can produce successful democratic leaders.

\section{Suggestion}

Based on the findings, few suggestions can be made in order to increase the leadership skills among the headmasters. Among others are, the concerned ministries and departments can organise programs especially for school leaders in order to improve their management and leadership style. This has to be taken into account because the development of the management field today is progressive and global in nature. The appointment of school leaders is based on seniority and experience may be questioned through how they carry out their tasks and responsibilities as school leaders. Are they capable to shoulder such responsibilities?

Not only that, educational visits to schools which have portrayed good administrative system and accel 
academically should be encouraged. These are crucial in ensuring best practices in terms of school management can be shared and ways to overcome the weaknesses and problems can be discussed. Besides, principals who act as transformational leaders can encourage creativity, open-mindedness and facilitate conditions and events that create a positive environment for technology adoption in order to encourage teachers to use technology in their teaching and learning process (Mojgan, 2012).

However, this paper is not without limitation, in which its needs further investigation. This paper only used a quantitative approach without control extra information from the another party for example; students, parents and others. Therefore, the further study can be extend by increase the number of samples with add on other party not only focused on judgement from teachers. Besides thats, the various of methods can be used like mixed methods.

As school leaders, the principals must be able to cope with a variety of issues, can think analytically and conceptually, should always play the role of a mediator in solving problems faced by teachers, and are invariably endeavouring to make decisions that can satisfy everyone. In order to achieve academic excellence, principals need to act smartly and systematically so that the strategy that has been planned can be implemented efficiently. Furthermore, the principal must be able to influence the school staff so that they will continuously strive for change.

\section{References}

Afshari, M., Ghavifekr, S., Siraj, S., \& Samad, R. S. A. (2012). Transformational Leadership Role of Principals in Implementing Informational and Communication Technologies in Schools. Life Science Journal, 9(1), 281-284. Retrieved from http://www.lifesciencesite.com/lsj/life0901/039_7635life0901_281_284.pdf

Antonio, D. M. S. (2008). Creating better schools through democratic school leadership. International Journal of Leadership in Education: Theory and Practice, 11(1), 43-62. http://dx.doi.org/10.1080/13603120601174311

Ashari, O. (1999). Club Management: A Guidelines. Kuala Lumpur: Utusan Publications \& Distributor Sdn. Bhd.

Aziz, J. A. (2002). Teachers' perceptions towards the effectiveness of school leaders in secondary school in Kubang Pasu District. Master Thesis (Educational Management). Universiti Utara Malaysia.

Block, P. (1993). Stewardship: Choosing service over self-interest. San Francisco: Berrett-Koehler.

Burnham, J W. (1999). Quality of Management in School, The Effective Strategy for Successful Quality. (Translation by Tengku Abd Aziz Tengku Zainal). Kuala Lumpur: Malaysia Institut of Translation \& Books.

Damit, M. (2002). Leadership style of headmasters in Religious schools in Temburong. Master Thesis (Islamic Studies), Universiti Brunei Darussalam.

Don, Y. (2005). Leadership of Educational in Malaysia. Kuala Lumpur: PTS Professional Publishing Sdn. Bhd.

Ghafar, M. N. A. (1999). Educational Research. Johor Darul Takzim: Universiti Teknologi Malaysia.

Imam, S. S. J. S., \& Ibrahim, M. S. (2010). Challenge the Leader in Managing Human Resoucers to produce Competent Teacher. Proceedings of the 4th International Conference on Teacher Education. UPI \& UPSI, 2010. Bandung, Indonesia, 8-10 November. Retrieved from http://goo.gl/zYWrwM

Kamis, M. K. (2003). Students' Academic Excellence: A correlational study on the leadership style, headmasters' management style and teachers' committment. Master Thesis (Educational Management). Universiti Utara Malaysia.

Keith, \& Girling. (1991). Education Management and Participation: New Directions in Educational Administration. Boston: Allyn amd Bacon.

Kouzes, J. M., \& Posner, B. Z. (1995). The leadership challenge: How to keep getting extraordinary things done in organizations (2nd ed.). San Francisco: Jossey-Bass.

Lebar, S. (2009). School Management in Malaysia and Brunei Darussalam: Excellent in Academic and Co-curiculum. Brunei, Dewan Bahasa \& Pustaka

Liman, M. (2008). Organisational leadership impact on the effectiveness of teaching and learning in Religious Schools in Brunei. Master Thesis (Islamic Studies). Universiti Brunei Darussalam.

Mahmood, H. (1993). Leadership and School Effectiveness. Kuala Lumpur: DBP.

Mamat, I. (1993). School Leadership: Theory for Practice. Kuala Lumpur: Kumpulan Budiman. 
Mamat, I. (2001). School Headmaster: The Leadership Issue and Challenges. Kuala Lumpur: Kumpulan Budiman.

Mohd, A. (2007). Theory and Technique of Leadership: A Guidelines in Workplace. Kuala Lumpur: PTS Professional Publication Sdn. Bhd.

Mohd, A., \& Hasan, A. (2001). Talent and Skills of Leadership. Kuala Lumpur: PTS Professional Publication Sdn. Bhd.

Moller, J., Eggen, A., Fugglestad, O. L., Langfeldt, G., Presthus, A. M., Skrovset, S., ... Vedoy, G. (2007). Successful Leadership Based on Democratic Values. Studies in Educational Leadership, 5(7), 71-86. http://dx.doi.org/10.1007/1-4020-5516-1_5

Mulyasa, E. (2009). Becoming an Excellent Headmaster. Bandung: PT Remaja Rosdakarya.

Ramaiah, A. (1992). Educational Leadership: Today's Challenges. Petaling Jaya IBS Buku Sdn. Bhd.

Salih, J. (2003). Leadership style of headmasters in National schools and its effects towards the students' achievements. Master Thesis (Education Management). Universiti Utara Malaysia.

Salleh, R. M. (2009). Teachers' and Students'perceptions towards the leadership of headmasters in Temburong district. Master Thesis (Islamic Studies), Universiti Brunei Darussalam.

Yusof, A. A. (2000). The Changes and Leadership. Kuala Lumpur: Universiti Utara Malaysia.

Yusoff, M. Y. (2000). Teachers' perceptions on the leadership style of Principals in Schools under Islamic Foundation of Kelantan. Master Thesis (Educational Management). Universiti Utara Malaysia.

\section{Copyrights}

Copyright for this article is retained by the author(s), with first publication rights granted to the journal.

This is an open-access article distributed under the terms and conditions of the Creative Commons Attribution license (http://creativecommons.org/licenses/by/3.0/). 